\title{
DANDY-WALKER SYNDROME IN ADULT MIMICKING MYASTHENIA GRAVIS
}

\author{
Juliana Cardoso, Marcos C. Lange, Paulo J. Lorenzoni, \\ Rosana H. Scola, Lineu C. Werneck
}

\begin{abstract}
The Dandy-Walker syndrome (DWS) is a rare posterior fossa malformation. The DWS can occur associated with other brain or systemic malformations, but ocular abnormalities in this disease are rare and clinical findings mimicking myasthenia gravis have not been described to date. We report a 23-yearold woman who presented mild limitation of the ocular movements with progressive palpebral ptosis, which changed in intensity during the day. The investigation showed negative anti-acetylcholine receptor antibody, repetitive nerve stimulation and "Tensilon test", but the brain magnetic resonance image reveals DWS with hydrocephalus associated with calosal dysgenesis. The characteristic of disease, clinical manifestations and pathologic features, specially the clinical evaluation of ocular abnormalities in suspicion of DWS, including the MG in differential diagnosis are discussed.
\end{abstract}

KEY WORDS: Dandy-Walker syndrome, hydrocephalus, myasthenia gravis, palpebral ptosis.

\begin{abstract}
Síndrome de Dandy-Walker em adulto simulando miastenia gravis
RESUMO - A síndrome de Dandy-Walker (DWS) é uma rara malformação da fossa posterior que pode ocorrer associada com outras malformações cerebrais ou sistêmicas. As alterações oculares são raras e as manifestações clínicas, simulando miastenia gravis (MG), não foram descritas até o momento. Descrevemos uma mulher de 23 anos apresentando discreta limitação da movimentação ocular com progressiva ptose palpebral que mudava de intensidade durante o dia. A investigação mostrou negativos o anticorpo anti-receptor de acetilcolina, a estimulação nervosa repetitiva e o "teste do Tensilon", porém a ressonância magnética de crânio revelou DWS com hidrocefalia associada à disgenesia de corpo caloso. As características da doença, manifestações clínicas e patológicas, especialmente a avaliação clínica de anormalidade ocular na suspeita de DWS serão discutidas, incluindo a MG no diagnóstico diferencial.
\end{abstract}

PALAVRAS CHAVE: síndrome de Dandy-Walker, hidrocefalia, miastenia gravis, ptose palpebral.

The Dandy-Walker syndrome (DWS) is a rare posterior fossa malformation, characterized by aplasia or hypoplasia of the cerebellar vermis, involving the cortex and deep cerebellar nuclei; the presence of a membranous cyst of the fourth ventricle; and, commonly, hydrocephalus ${ }^{1,2}$. This malformation was first described by Dandy and Blackfan (1914) ${ }^{3}$. Taggart and Walker (1942) revised this malformation characterizing the main clinical and pathologic features ${ }^{4}$. Benda (1954) finally labeled the disease as "DandyWalker syndrome" . Initially, the DWS was reported in Brazil by Almeida (1960)6.

The DWS can occur associated with other malformations of the brain, as calosal agenesis, and other systemic abnomalies'. Several other structured lesions of the central nervous system, such as cerebrovascu- lar disease, brain stem tumors and Chiari malformation were described as mimicking MG, due to involvement or compression of the brain stem, could easily lead to misdiagnosis and an inappropriate treatment, but the DWS have not been reported to date ${ }^{1,2,6-12}$.

The clinical presentation of dysfunction of the neuromuscular junction mimicked the DWS have not been reported to date and for this reason we report this case.

\section{CASE}

A 23-year-old woman presented mild limitation of the ocular movements with progressive palpebral ptosis, who changed in intensity from day to day and during the day, according to the intensity of physical activity, since the age of 19 years without diplopia. She was born at term and was the first child of non-consanguineous parents and the only

Neuromuscular/Neurology Division, Internal Medicine Department, Hospital de Clínicas da Universidade Federal do Paraná, Curitiba PR, Brazil (UFPR).

Received 10 July 2006, received in final form 22 September 2006. Accepted 8 November 2006.

Dra. Rosana Herminia Scola - Serviço de Doenças Neuromusculares / Hospital de Clínicas da UFPR - Rua General Carneiro 181 / $3^{\circ}$ andar - 80060-900 Curitiba PR - Brasil. E-mail: scola@hc.ufpr.br 


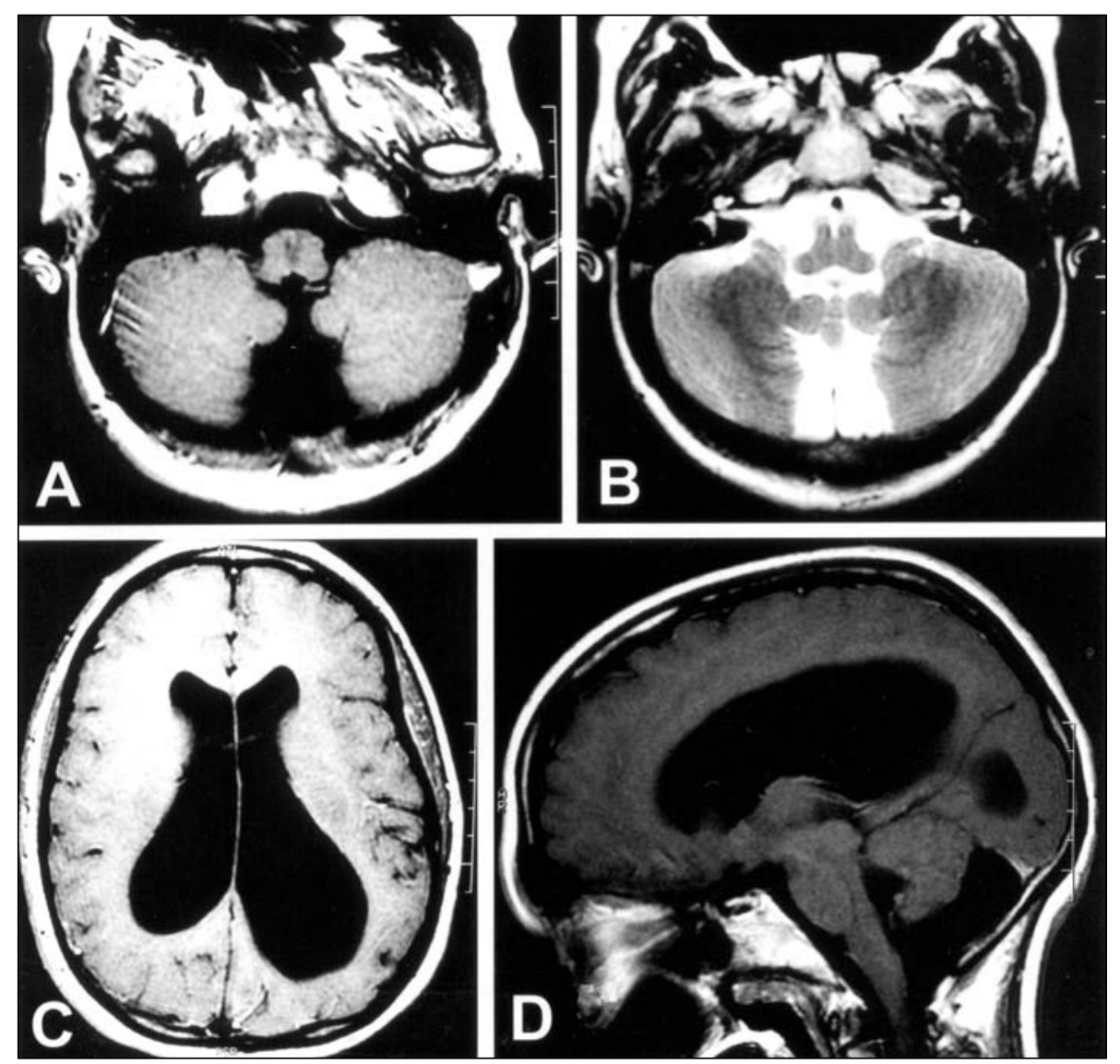

Figure. Typical features of Dandy-Walker variant on brain MRI: (A) large fourth ventricle in axial T1-weighted image; (B) small cerebellar vermis in axial T2-weighted image; (C) hydrocephalus in axial T1-weighted image; and (D) dysgenesis of the corpus callosum in sagittal T1-weighted image.

affected case in the family. The psychomotor development was normal.

Physical examination did not reveal abnormalities. Neurological examination showed intellectually normal; asymmetrical palpebral ptosis (right>left) associated with bilateral ocular lateral rectus muscle weakness; saccades and pupils reflexes were preserved, absence of papilledema and nystagmus; generalized hypotonia; symmetrical muscle strength grade 4 (Medical Research Council Scale) in proximal upper limbs and grade 5 in lower limbs; deep tendon reflexes, gait and all sensory examinations were normal.

The symptoms and signs were thought to be consistent with myasthenia gravis, but the investigation showed the following results: (1) anti-acetylcholine receptor antibody normal ( $0.15 \mathrm{nmol}$; normal: $<0.20 \mathrm{nmol})$; (2) needle electromyography, motor and sensory nerve conduction studies were normal; (3) repetitive stimulation of the facial, spinal accessory and ulnar nerves at $3 \mathrm{~Hz}$ were normal; and (4) "Tensilon test" (10 mg of edrophonium intravenous preceded by atropine) and use of pyridostigmine (180 mg/daily) did not improve the ocular palsies.

After this initial investigation the patient was submitted to magnetic resonance imaging (MRI) that revealed hydrocephalus, cerebellar vermis hypoplasia, posterior fossa cyst (large fourth ventricle) and dysgenesis of the corpus callosum (Figure).

All studies were done following informed consent.

\section{DISCUSSION}

The DWS is a very rare congenital malformation of the posterior fossa, with an incidence ranging between $1 / 25000$ and $1 / 35000$ births, usually observed during the prenatal period or early infancy and more rarely in adults ${ }^{1,2}$. The DWS is characterized by a hypoplasia or agenesis of the cerebellar vermis, involving the cortex and deep cerebellar nuclei, enlargement of the fourth ventricle in continuity with a posterior fossa cyst, and usually, though not exclusively, hydrocephalus $^{1,7}$. There is some doubt if the malformation is simply due to congenital obstruction of the foramina of Luschka and Magendie, which results in ballooning of the fourth ventricle and deformity of the cerebellum of varying degree, or represents a structural developmental anomaly of the area of the fourth ventricle $e^{1,6,12}$. 
Various predisposing factors have been reported such as infections, cranial trauma, chronically disturbance in cerebrospinal fluid pressure, persistence of embryonic tissue, vascular lesions, teratogenesis and maternal diabetes ${ }^{1,7,13}$. The DWS has been frequently associated with trisomies $3 q, 6 p, 9 p, 11$ or 22 , and more rarely with chromosome translocations ${ }^{13}$. More recently, a first critical region associated with DWS, encompassing two adjacent Zinc finger in cerebellum genes, ZIC1 and ZIC4 has been identified ${ }^{13}$.

In DWS patients focal neurological signs are usually less prominent, but symptoms and signs of hydrocephalus are more frequent $t^{1,6,12,14}$. In most previous series of DWS, approximately $40 \%$ of the children were intellectually normal, $40 \%$ had mental retardation, and $20 \%$ were borderlines, but our case is intellectually normal ${ }^{7}$. Seizures, cerebellar ataxia and dizziness, when present, become manifest during the first years of life $1,6,13$. Symptoms suggestive of increased intracranial pressure such as lethargy, vomiting and nystagmus may also appear during the evolution ${ }^{1,13}$. The associated neurodevelopmental abnormalities were also less severe in adults cases compared with those reported in early infancy ${ }^{13}$. The patients with minor abnormalities degrees can remain assymptomatic until later in life and then present with hydrocephalus $^{12-14}$.

In this context, the preserved cortical cytoarchitecture and the rarity of additional neurodevelopmental changes in DWS adults may explain the mild or absence of clinical expression, compared with DWS infants $^{13}$. Structural imaging in eigth previously described adult cases also show a relative paucity of neurodevelopmental abnormalities ${ }^{13}$.

The clinical manifestation of the DWS depending of the degree of the malformations and other brain or systemic abnormalities associated, but abnormal eye movements with palpebral ptosis has been rarely reported in DWS. In our case, bilateral abducens nerve palsy can be attributed to the hydrocephalus (traction on the abducens nerves as it is tethered at the petroclinoid ligament). Also, the palpebral ptosis can be attributed to the hydrocephalus, because in chronic cases a change in the cerebrospinal fluid pressure gradient, between the ventricles and the brain, can produce a transient disturbance of the periaqueductal structures (ventral), resulting in the development of palpebral ptosis ${ }^{15}$. Lepore also reported a series of
13 patients with bilateral palpebral ptosis after acute right fronto-temporo-parietal lobe lesions ${ }^{16}$. The changed of palpebral ptosis and lateral rectus weakness from day to day and according physical activity can be explained by hydrocephalus (change in the cerebrospinal fluid pressure).

The ocular abnormalities are found more frequent in MG and rarely in DWS, reason for which the initial diagnosis was MG in our patient.

Also, in agreement with the structural imaging data reported, this case suggests that the presence of chronic hydrocephalus in adult form of DWS may mimic dysfunction of the neuromuscular junction, as MG. This finding is important to remember to neurologists that patients with ocular form of the myasthenia gravis and normal investigation or atypical clinical characteristics must be submitted to brain images for differential diagnosis.

\section{REFERENCES}

1. Hart MN, Malamud N, Ellis WG. The Dandy-Walker syndrome: a clinicopathological study based on 28 cases. Neurology 1972;22:771-780.

2. Hirsch JF, Pierre-Kahn A, Renier D, et al. The Dandy-Walker malformation. J Neurosurg 1984;61:515-522.

3. Dandy WE, Blackfan KD. Internal hydrocephalus: an experimental, clinical and pathological study. Am J Dis Child 1914;8:406-482.

4. Taggart JK, Walker AE. Congenital atresia of the foramens of Luschka and Magendie. Arch Neurol Psychiat 1942;48:583-612.

5. Benda CE. The Dandy-Walker syndrome or the so-called atresia of the foramen Magendie. J Neuropathol Exp Neurol 1954;13:14-29.

6. Almeida GM. Síndrome de Dandy-Walker: a propósito de quatro casos. Arq Neuropsiquiatr 1960;18:224-238.

7. Klein O, Pierre-Kahn A, Boddaert N, Parisot D, Brunelle F. Dandy-Walker malformation: prenatal diagnosis and prognosis. Childs Nerv Syst 2003;19:484-489.

8. Frisby J, Wills A, Jaspan T. Brain stem compression by a giant vertebrobasilar aneurysm mimicking seronegative myasthenia. J Neurol Neurosurg Psychiatry 2001;71:125-126.

9. Dirr LY, Donofrio PD, Patton JF, Troost BT. A false-positive edrophonium test in a patient with a brainstem glioma. Neurology 1989;39: 865-867.

10. Straube A, Witt TN. Oculo-bulbar myasthenic symptoms as the sole sign of tumour involving or compressing the brain stem. J Neurol 1990; 237:369-371.

11. Rodolico C, Girlanda P, Nicolosi C, Vita G, Bonsignore M, Tortorella G. Chiari I malformation mimicking myasthenia gravis. J Neurol Neurosurg Psychiatry 2003;74:393.

12. Costa JC, Anicet A, Coutinho MF. Síndrome de Dandy-Walker. Arq Neuropsiquiatr 1973;31:46-52.

13. Notaridis G, Ebbing K, Giannakopoulos P, Bouras C, Kövari E. Neuropathological analysis of an asymptomatic adult case with DandyWalker variant. Neuropathol Appl Neurobiol 2006;32:344-350.

14. Taylor FR, Larkins MV. Headache and Chiari I malformation: clinical diagnosis, and controversies in management. Curr Pain Headache Rep 2002;6:331-337.

15. Suzuki H, Matsubara T, Kanamaru K, Kojima T. Chronic hydrocephalus presenting with bilateral ptosis after minor head injury: case report. Neurosurgery 2000;47:977-979.

16. Lepore FE. Bilateral cerebral ptosis. Neurology 1987;37:1043-1046. 